\title{
Decolonising the Criminology curriculum in South Africa: Views and experiences of lecturers and postgraduate students
}

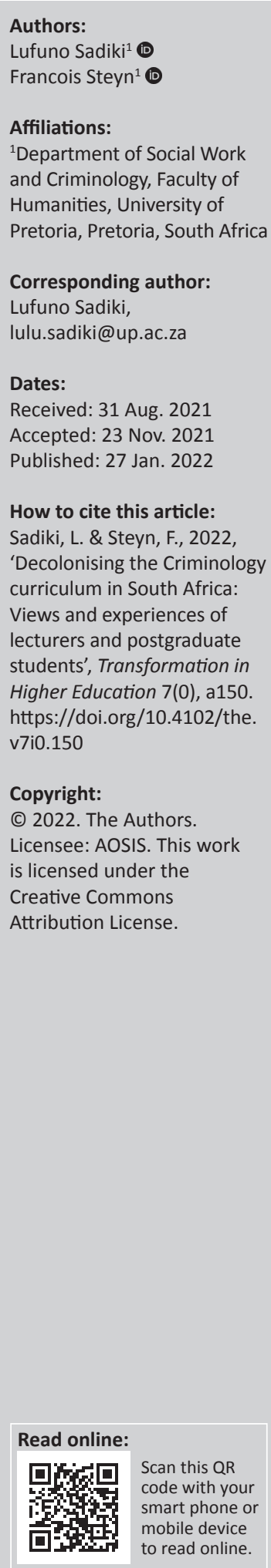

Background: For many years, the lived experiences, knowledge systems and histories of previously colonised people have been misinterpreted, removed and devalued in university teaching. The present curricula of African universities are predominantly Eurocentric and Criminology is no exception. In the wake of the \#RhodesMustFall student protest action, there is a recognition and need to include African epistemology within the discipline of Criminology.

Aim: The study investigated the views of lecturers and postgraduate students regarding the content, transformation and decolonisation of Criminology curricula.

Setting: South African universities offering Criminology as a degree and/or academic subject.

Methods: A total of 87 respondents, 42 lecturers and 45 postgraduate students, voluntarily participated in an online survey. Lecturers were purposively selected whilst postgraduate students were recruited via snowball sampling.

Results: Nearly all the respondents had heard of decolonisation before, with the majority of the academic staff members being aware of it prior to \#RhodesMustFall. Respondents agreed that the Criminology curriculum needs to be decolonised, with statistically significant differences emanating between black lecturers and white lecturers.

Conclusion: Decolonisation and transformation have been debated for many years without meaningful translation in and changes to Criminology curricula.

Keywords: Criminology; curriculum; transformation; decolonisation; teaching and learning.

\section{Introduction}

Institutions of higher learning (IHL) in Africa continue to replicate Western ideologies without considering the continent's context and realities (Mswazie \& Mudyahoto 2013:170). It is almost three decades since apartheid was abolished and South Africa became a democratic country, yet neo-colonialist, structural imbalances and imperialist practices continue to persist in many spheres of society, including higher education (Heleta 2016:2). Many universities have been struggling to transform from their colonial past of being characterised by White dominance and European worldviews, to becoming more inclusive IHL that cater for the educational needs of a diverse South Africa (Ndlovu-Gatsheni \& Zondi 2016:4). Historically, South African knowledge systems have been suppressed by colonialism and apartheid (Luckett 2010:5) with apartheid manifesting in epistemologies, methodology, ontology, gender biases, patriarchy and racism (Denzin, Lincoln \& Smith 2008:22; Keet 2014:23).

The \#RhodesMustFall student protest actions in 2015 ignited the call to decolonise South African universities and their curricula. The student movement laid bare fundamental problems of postapartheid higher education, highlighting issues concerning access, institutional racism and exclusion (Le Grange 2019:29). Initially, the movements called for the removal of the statue of the British imperialist Cecil John Rhodes from the campus of the University of Cape Town (UCT). The movement petitioned for a free, decolonised and African-centred curriculum (Sadiki 2020:640). The statue was interpreted as a symbol of colonial empire and the call for its removal was a means of challenging orthodox historical consciousness. Therefore, what remains is to remove the 'Rhodes' that underpins academic curricula (Garuba 2015; Jansen 2019:51). In addition, the student protest actions were marred by violence, which is not surprising because of the sudden

Note: Special Collection: COVID-19. 
awareness of the fundamental flaws within the system that remained unchanged and the continuation of a paradigm that simply did not match local reality, which is remnant of apartheid. Fanon (1963), in his analysis of violence in the struggle for freedom, justified violence as an appropriate response when facing colonial oppression.

Decolonisation of South African IHL, epistemology and disciplines was an essential purpose of the student movements (Ndlovu-Gatsheni \& Zondi 2016:4-5; Shay 2016). Decolonisation is a contested term that has diverse meanings across different contexts (Mackinlay \& Barney 2014:54; Zembylas 2018:1). The term has a rich intellectual ancestry and was first introduced in the 1960s and gained steam in the 1980s as popularised by Fanon (1963) and Ngugi wa Thiongi (1986). For Ngugi (1986), decolonisation does not entail merely removing and completely doing away with Eurocentric perspectives but placing Africa at the centre of teaching, learning and research. The current curriculum marginalises and subjugates African perspectives and epistemologies in favour of Eurocentric domination. The term entails dismantling the remnants of colonialism, which is prevalent in the Eurocentric nature of the curriculum offered at post-colonial universities (Jansen 2019:52), which privileges Western knowledge system above the rest (Keet 2014:23).

Within the South African context, decolonisation encapsulates power relations in knowledge production and begs the question 'whose knowledge is at the centre of the continental contestation over the curriculum' (Jansen 2019:53). For students, decolonisation was the remedy for the lack of transformation at South African universities. As cogently captured by Le Grange (2019:31-32), 'decolonisation does not have to mean or involve destruction' and often what has 'been decolonised has the potential to produce colonising effects and vice versa'. The terms transformation and decolonisation have erroneously been used interchangeably. Transformation is not decolonisation. Transforming the curriculum entails creating a curriculum that is responsive to the social context and prioritises previously marginalised narratives, voices and knowledge systems. However, decolonisation is far more salient than replacing Western theories and authors with African ones (Mgqwashu 2016). One of the menacing problems confronting decolonisation is determining how the concept relates to African epistemology and Africanisation. African epistemology refers to how Africans 'conceptualises, interprets and apprehends reality within the context of African cultural or collective experience' (Anyanwu 1983:60). In the context of higher education, Africanisation entails centring the life experiences, traditions, culture, histories and voices of the African people in the curriculum (Thabede 2008:234). To Africanise the curriculum, colonial roots that underpin it ought to be dismantled (Jansen 2019:52) to make room for African modes of knowledge and understanding (Udefi 2014:108). Therefore, without decolonisation, Africanisation cannot take place and ultimately transformation cannot be achieved without both decolonisation and Africanisation (Chimakonam 2019:182).
The point of origin and theorising of texts being studied in Criminology has colonial roots (Williams \& Chrisman 1995:5) and presents a Western perspective of the social world (Kalunta-Crumpton 2004:5). Criminology is dominated by Western scholars, literature and perspectives (Moosavi 2018:230; Williams \& Chrisman 1995:5), resulting in crime and the criminal justice system conceptualised from a Western perspective (Kalunta-Crumpton 2004:5) and a discipline that fails to solve the crime problem (Agozino 2004:351). Instead of generalising Criminology theories to the African continent, the discipline ought to discover better answers to solve crime (Agozino 2004:351). No other social science has served colonialism more directly than Criminology and the discipline has been classified as an imperialist science for the control of others (Agozino 2004:343; King 2017:2-3; Moosavi 2018:230-231). Agozino (2010:i-ii) emphasises the oppressive and authoritarian nature of Criminology by labelling the discipline as a 'technology designed for the control of others' and a 'control freak discipline'. His views echo sentiments of Foucault (1977) about the utility of Criminology because the discipline itself is embedded in and reliant on Western justice systems and how offenders are supposed to be 'managed' without acknowledging how remnants of colonialism continue to influence crime and criminality. Furthermore, there is a lack of understanding of how the effect of colonialism has perpetuated the operation of systems such as the criminal justice system (Cunneen \& Rowe 2014:49).

To date there have been limited attempts to include theoretical and practical implications of African understandings and approaches within Criminology and much of the discipline's knowledge has always been concentrated in a few hands (Agozino 2004:343; Moosavi 2018). This in turn contributed to the marginalisation of the subjects it seeks to study (Deckert 2014:49). Decolonisation and post-colonial perspectives have had greater impact in disciplines such as Literature, Law, Politics, Philosophy and Sociology, yet postcolonial perspectives in Criminology remain constrained. Therefore, decolonising Criminology is necessary and can only be achieved by employing critical research (Denzin et al. 2008:21). This article aims to explore the curriculum content of Criminology at South African universities to determine to what extent African perspectives are reflected in the subject content and teaching approaches and unpacks the views of lecturers and postgraduate students regarding the content of the discipline's curriculum. With the call to decolonise and transform institutions becoming more urgent, the curriculum is an important aspect of the decolonial project as it ultimately determines whose knowledge is learned, valued and reproduced.

\section{Research methodology and design}

Using a quantitative research method, a cross-sectional survey was administered to academic staff members and postgraduate students at South African IHL. The survey generated insights into the attitudes, opinions and expectations 
of respondents regarding transformation and decolonisation of Criminology curricula (Creswell \& Creswell 2018:49; Maree \& Pietersen 2017:174). The non-probability sampling method entailed purposive and snowball sampling techniques. The study warranted respondents who were informative, useful and appropriate for the topic at hand (Babbie 2016:187; Neuman 2014:273-274). Postgraduate students were selected on the notion that they have a higher level of understanding, critical thinking skills and specialised knowledge about Criminology and should be able to work and learn independently as opposed to undergraduate students. Academic staff members are primarily responsible for teaching and learning and curriculum development hence their inclusion in the study. Lecturer respondents were purposively identified from the websites of the various Criminology departments and were subsequently invited by email to participate in the survey. Postgraduate students were considered an unknown population (registration information is not in the public domain), therefore, snowball sampling was used where academic staff respondents who participated in the survey were asked to forward the survey invitation to their postgraduate students (De Vos et al. 2011:393; Kumar 2014:244).

Data were collected by means of a rapid online survey administered through Qualtrics (2020). The platform was user friendly and had quality control features that prevented multiple submissions from single respondents. The online survey was piloted with two respondents to test the procedures and ensure the content validity of the instrument (Creswell \& Creswell 2018:154). Respondents were sent an anonymous link and no information that could identify them (name, surname, institutions and email address) was captured. The survey was available for 2 weeks, after which the data were exported to Statistical Package for the Social Sciences (SPSS) (IBM Corp 2020) for statistical analysis. Considering the study's sampling strategy and the data not showing normal distributions, the Mann-Whitney $U$ test was used to determine any statistically significant differences (IBM 2020). In cases where a statistically significant difference featured $(p<0.05)$, effect sizes were calculated where $r=-0.1$ indicates a weak, $r=-0.3$ notes a medium and $r=-0.5$ points to a large effect size. The study was approved by the Research Ethics Committee of the Faculty of Humanities of the University of Pretoria (HUM026/1119) and all the participating universities agreed to have their Criminology lecturers and postgraduate students complete the survey. The landing page of the survey had an ethics statement and a function for respondents to tick that they agree to voluntarily participate in the survey. An informed consent leaflet was attached that detailed the purpose of the study and assured respondents of anonymity and confidentiality of the information they shared.

The sample is not representative of all South African universities and the findings should, therefore, be generalised with caution (Neuman 2014:248). In addition, the sampling strategy could have resulted in selection bias (in other words, only those respondents who are interested in debates about transformation and decolonisation participated in the survey), thus giving rise to a skewed sample of Criminology lecturers and postgraduate students. Except for biographic information (gender, age, populationgroup and academic position/highestqualification), the academic staff and postgraduate student data are presented jointly because of low n-values. Where significant differences featured, these are indicated and unpacked as such. Indian and mixed-race respondents were left out of statistical analyses because of low n-values.

All respondents were asked closed-ended questions about their understanding of decolonisation and what it entails for higher education, the content of their Criminology curricula and their views on the need for decolonisation. Postgraduate students were asked about the extent to which they encountered indigenous versus Eurocentric perspectives in their learning. Both groups were offered the opportunity to motivate their answers in the form of open-ended questions. These insights are presented as direct quotes and are accompanied by supporting literature to validate their meaning. For the purpose of this paper each respondent's response to the open-ended question is assigned a respondent number (i.e. Respondent 1 to Respondent 87). The researchers aimed to obtain data from at least 100 respondents and despite reminders, personalised emails and stating the average time it would take to complete the survey had a low response rate featured. The low response rate could be attributed to 'survey fatigue' and lack of data, especially on the part of postgraduate students because the respondents had to use their own data to complete the survey.

\section{Ethical considerations}

Ethical clearance to conduct this study was obtained from the University of Pretoria Humanities Research Ethics Committee (No. HUM026/1119).

\section{Results \\ Sample characteristics}

A total of 87 respondents completed the survey of whom slightly more than half $(n=45 ; 52 \%)$ were postgraduate students and the remaining were academic staff members $(n=42 ; 48 \%)$. Nearly a third $(n=28 ; 32 \%)$ of respondents were male and almost half $(n=41 ; 47 \%)$ were between the ages of 20 and 30 (Table 1).

Two in five $(n=17 ; 41 \%)$ of the academic respondents were lecturers and nearly a third $(n=13 ; 31 \%)$ were senior lecturers. Very few respondents were junior lecturers $(n=2 ; 5 \%)$, associate professors $(n=3 ; 7 \%)$ and honorary professors $(n=2 ; 5 \%)$, with only $12 \%(n=5)$ holding the position of full professor. Respondents' years of lecturing experience ranged between 1 and more than 20 years, with more than a quarter (27\%) having had 6 to 10 years of lecturing, 2 in $5(n=9 ; 22 \%)$ with 1 to 5 years and 11 to 15 years' experience, respectively. Nearly a fifth $(n=7 ; 17 \%)$ had more than 20 years of lecturing experience. 
TABLE 1: Biographic information of respondents.

\begin{tabular}{|c|c|c|c|c|c|c|}
\hline \multirow[t]{2}{*}{ Biographic variables } & \multicolumn{2}{|c|}{ Total } & \multicolumn{2}{|c|}{$\begin{array}{l}\text { Academic } \\
\text { staff }\end{array}$} & \multicolumn{2}{|c|}{$\begin{array}{c}\text { Postgraduate } \\
\text { student }\end{array}$} \\
\hline & $N$ & $\%$ & $n$ & $\%$ & $n$ & $\%$ \\
\hline \multicolumn{7}{|l|}{ Gender } \\
\hline Female & 59 & 68 & 22 & 52 & 8 & 18 \\
\hline Male & 28 & 32 & 20 & 48 & 37 & 82 \\
\hline \multicolumn{7}{|l|}{ Age } \\
\hline $20-30$ & 41 & 47 & 6 & 14 & 35 & 78 \\
\hline $31-40$ & 21 & 24 & 14 & 33 & 7 & 16 \\
\hline $41-50$ & 15 & 17 & 14 & 33 & 1 & 2 \\
\hline $51-60$ & 8 & 9 & 6 & 14 & 2 & 4 \\
\hline$>61$ & 2 & 2 & 2 & 5 & - & - \\
\hline \multicolumn{7}{|l|}{ Population group } \\
\hline Black people & 49 & 56 & 25 & 60 & 24 & 53 \\
\hline White people & 30 & 35 & 13 & 31 & 17 & 37 \\
\hline Indian & 4 & 5 & 3 & 7 & 1 & 2 \\
\hline Mixed-race & 4 & 4 & 1 & 2 & 3 & 7 \\
\hline \multicolumn{7}{|c|}{ Highest qualification/degree enrolled for } \\
\hline Honours & 26 & 30 & 1 & 3 & 25 & 56 \\
\hline Master's degree & 31 & 36 & 19 & 45 & 12 & 27 \\
\hline Doctoral degree & 28 & 32 & 21 & 50 & 7 & 16 \\
\hline Honorary professor & 1 & 1 & 1 & 2 & - & - \\
\hline Postdoctoral & 1 & 1 & - & - & 1 & 2 \\
\hline
\end{tabular}

\section{Understanding of decolonisation and what it entails for higher education}

All the academic respondents $(n=42 ; 100 \%)$ and the majority of postgraduate respondents $(n=42 ; 93 \%)$ had heard of decolonisation before. A total of $56 \%(n=23)$ of the academic respondents knew about decolonisation prior to the 2015 student protest action, one in five heard of it during the protest $(n=8 ; 20 \%)$, and $12 \%(n=5)$ heard about it after the protest action. Furthermore, $12 \%(n=5)$ of the academic staff heard about decolonisation from other sources such as seminars and from the academic community. More than a quarter $(n=19 ; 28 \%)$ of the postgraduate students heard about decolonisation from their prescribed learning material and the media, respectively. Only $2(5.0 \%)$ postgraduate respondents heard about decolonisation from university management, $13 \%(n=9)$ from the \#FeesMustFall protest action and student activist or leadership structures and a tenth $(n=7 ; 11 \%)$ of the student respondents learnt about decolonisation from their own research.

The bulk of the respondents agreed that decolonisation of higher education entailed placing African knowledge on an equal footing with current Western knowledge $(n=76 ; 94 \%)$ and reconstructing the current Criminology curriculum to make it more inclusive $(n=77,95 \%)$. A quarter of the respondents $(n=21 ; 26 \%)$ were neutral in recognising that knowledge is marked by power relations (Table 2).

Nearly two-thirds of black respondents ( $n=22 ; 65 \%$ ) compared with a third of white respondents $(n=11 ; 32 \%)$ agreed that decolonisation entails rooting educational paradigms in indigenous African epistemological frameworks, displaying a statistically significant difference with a medium to large effect size $(p=0.015 ; r=-0.41)$.
TABLE 2: What decolonisation entails for higher education.

\begin{tabular}{|c|c|c|c|c|c|c|}
\hline \multirow[t]{2}{*}{ Statements on decolonisation } & \multicolumn{2}{|c|}{ Agree } & \multicolumn{2}{|c|}{ Neutral } & \multicolumn{2}{|c|}{ Disagree } \\
\hline & $n$ & $\%$ & $n$ & $\%$ & $n$ & $\%$ \\
\hline $\begin{array}{l}\text { Placing African knowledge on equal } \\
\text { footing with Western knowledge }\end{array}$ & 76 & 94 & 2 & 3 & 3 & 4 \\
\hline $\begin{array}{l}\text { Recognising that knowledge is not } \\
\text { owned by anyone }\end{array}$ & 67 & 83 & 8 & 10 & 6 & 7 \\
\hline $\begin{array}{l}\text { Recognising that knowledge is } \\
\text { marked by power relations }\end{array}$ & 52 & 64 & 21 & 26 & 8 & 10 \\
\hline $\begin{array}{l}\text { Reconstructing the current curriculum } \\
\text { to make it more inclusive }{ }^{1}\end{array}$ & 77 & 95 & 4 & 5 & - & - \\
\hline $\begin{array}{l}\text { Identifying the ways university } \\
\text { reproduces colonial hierarchies }\end{array}$ & 63 & 78 & 11 & 14 & 7 & 9 \\
\hline $\begin{array}{l}\text { Creating spaces for a dialogue amongst } \\
\text { members of the university }\end{array}$ & 78 & 96 & 3 & 4 & - & - \\
\hline $\begin{array}{l}\text { Belief that any knowledge could and } \\
\text { should be open to challenge and } \\
\text { question regardless of its origin }\end{array}$ & 75 & 93 & 4 & 5 & 2 & 3 \\
\hline $\begin{array}{l}\text { * Rooting educational paradigms in } \\
\text { indigenous African epistemological } \\
\text { frameworks }\end{array}$ & 74 & 91 & 5 & 6 & 2 & 3 \\
\hline
\end{tabular}

TABLE 3: Content of Criminology curriculum.

\begin{tabular}{|c|c|c|c|c|c|c|}
\hline \multirow[t]{2}{*}{ Curriculum content } & \multicolumn{2}{|c|}{ Frequently } & \multicolumn{2}{|c|}{ Occasionally } & \multicolumn{2}{|c|}{ Seldom } \\
\hline & $n$ & $\%$ & $n$ & $\%$ & $n$ & $\%$ \\
\hline $\begin{array}{l}\text { Allows students to understand the } \\
\text { origins of Criminology in its historical } \\
\text { context }\end{array}$ & 48 & 63 & 22 & 29 & 7 & 9 \\
\hline $\begin{array}{l}\text { Cultivates an appreciation for } \\
\text { diverse entry points around a } \\
\text { particular subject* }\end{array}$ & 38 & 49 & 24 & 31 & 15 & 20 \\
\hline $\begin{array}{l}\text { Provides students opportunities in } \\
\text { their learning to widen their circles } \\
\text { of contact or experience* }\end{array}$ & 38 & 49 & 26 & 34 & 13 & 17 \\
\hline $\begin{array}{l}\text { Incorporates Afrocentrism in the } \\
\text { explanation and causation of crime }\end{array}$ & 34 & 44 & 19 & 25 & 24 & 31 \\
\hline $\begin{array}{l}\text { Includes traditional methods of } \\
\text { conflict resolution* }\end{array}$ & 26 & 34 & 14 & 18 & 37 & 48 \\
\hline $\begin{array}{l}\text { Promotes Western ideologies and } \\
\text { epistemologies }\end{array}$ & 60 & 78 & 13 & 17 & 4 & 5 \\
\hline $\begin{array}{l}\text { Allows students to engage with } \\
\text { diverse local and global perspectives }\end{array}$ & 44 & 55 & 27 & 35 & 8 & 10 \\
\hline $\begin{array}{l}\text { Inspires students to engage with } \\
\text { issues such as discrimination, racism, } \\
\text { inequality, colonialism and inclusion }\end{array}$ & 41 & 53 & 21 & 27 & 15 & 20 \\
\hline
\end{tabular}

*, Significant difference at $p<0.05$.

Three quarters ( $n=60 ; 78 \%)$ of the respondents stated that the current Criminology curricula promoted Western ideologies and epistemologies whilst nearly half $(n=37 ; 48 \%)$ reported that African traditional methods of conflict resolution were seldom included (Table 3). ${ }^{1,2}$

A statistically significant difference with a medium effect size ( $p=0.011 ; r=-0.28)$ featured between lecturers and students regarding the statement that Criminology curricula cultivate an appreciation for diverse entry points, with most lecturers stating that it happens frequently $(n=24 ; 64 \%)$ compared with three in five $(n=24 ; 60 \%)$ students who stated that this seldom happened. Nearly two-thirds $(n=23$; $62 \%$ ) of the academic staff indicated that they frequently provided students with opportunities to widen their circles of contact or experience in their learning, although more than half of students $(n=22 ; 55 \%)$ stated that these opportunities rarely occurred ( $p=0.008 ; r=-0.30)$.

1.An inclusive curriculum is one that is representative of the diverse student body, their thoughts and lived experiences (Heleta 2016:3; Schucan Bird \& Pitman 2020:904).

2.Rooting educational paradigms in indigenous African epistemological frameworks entails that 'all educational curricula in Africa should have Africa as their focus and as a result be indigenous-grounded and orientated' (Higgs 2012:39). 


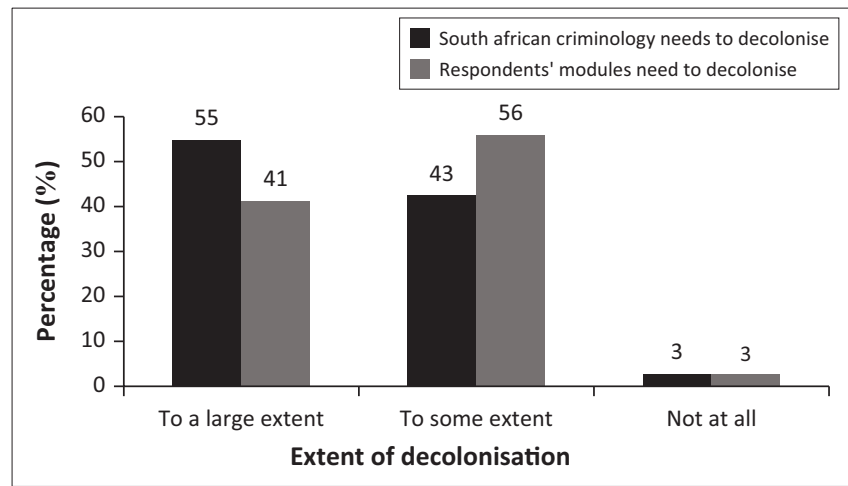

Figure 1: Should Criminology and its curriculum be decolonised?

TABLE 4: Indigenous versus Eurocentric perspectives in Criminology curriculum (postgraduate student responses)

\begin{tabular}{|c|c|c|c|c|c|c|}
\hline \multirow[t]{2}{*}{ Curriculum perspectives } & \multicolumn{2}{|c|}{ Frequently } & \multicolumn{2}{|c|}{ Occasionally } & \multicolumn{2}{|c|}{ Seldom } \\
\hline & $n$ & $\%$ & $N$ & $\%$ & $n$ & $\%$ \\
\hline $\begin{array}{l}\text { Encounter indigenous } \\
\text { perspectives in criminology }\end{array}$ & 6 & 15 & 15 & 39 & 18 & 46 \\
\hline $\begin{array}{l}\text { Current curriculum relevant to } \\
\text { African students and African } \\
\text { conditions. }\end{array}$ & 13 & 33 & 17 & 44 & 9 & 23 \\
\hline $\begin{array}{l}\text { Learn predominantly Eurocentric } \\
\text { and other Western theories }\end{array}$ & 33 & 85 & 6 & 15 & - & - \\
\hline $\begin{array}{l}\text { Engage with Indigenous } \\
\text { Knowledge Systems }\end{array}$ & 9 & 23 & 12 & 31 & 18 & 46 \\
\hline $\begin{array}{l}\text { Ideas and perspectives within } \\
\text { the curriculum challenge one's } \\
\text { perspective }\end{array}$ & 21 & 54 & 12 & 31 & 6 & 15 \\
\hline $\begin{array}{l}\text { Individual's culture and lived } \\
\text { experience is present in the } \\
\text { curriculum }\end{array}$ & 16 & 41 & 14 & 36 & 9 & 23 \\
\hline
\end{tabular}

Furthermore, more than half $(n=22 ; 55 \%)$ of the students stated that African methods of conflict resolution were seldom incorporated in the curriculum compared with two in five $(n=15 ; 40 \%)$ of the lecturers who indicated it to be frequently included $(p=0.040 ; r=-0.23)$.

\section{Decolonising Criminology curricula}

More than half of the respondents $(n=40 ; 55 \%)$ agreed that the Criminology curriculum need to be decolonised (Figure 1), with statistically significant differences $(p=0.14 ; r=-0.41)$ between black academic staff respondents $(n=18 ; 60 \%)$ and white academic staff respondents $(n=11 ; 37 \%)$. In addition, significantly more black respondents $(n=20 ; 56 \%)$ than white respondents $(n=15 ; 42 \%)$ stated that their modules need to be decolonised ( $p=0.41 ; r=-0.37)$.

Nearly half $(n=18 ; 46 \%)$ of the student respondents stated that they seldom encountered indigenous perspectives in their Criminology curriculum (Table 4). Furthermore, the greater proportion $(n=33 ; 85 \%)$ of the students reported frequently learning Eurocentric theories of crime and criminality.

\section{Responses from the open-ended questions}

Regarding decolonising and redesigning the curriculum, Garuba (2015) posed two questions: do we simply add new items to an existing curriculum or do we restructure the curriculum by objectively thinking how the curriculum itself is constituted? Many South African universities prefer 'adding items' to existing curricula as a means to maintain the status quo, which allows them to tick boxes as though transformation is taking place even though it is not (Heleta 2016:5). There is a growing acknowledgement from academic staff of the importance of incorporating African perspectives into the discipline to ensure that the curriculum is founded on critical Africa-centred epistemology (King 2017:10). The academic respondents held different views and approaches to decolonising and transforming their curricula. Some respondents felt that decolonising their curricula entailed incorporating African philosophies and worldviews as stated below:

'By incorporating the Africanised philosophies and use sources and literature written by African scholars.' (Respondent 9)

'Currently incorporating African narratives to outline some theoretical perspectives.' (Respondent 29)

'Decolonisation and transformation is an ongoing project. In South African Criminology, and the modules I teach, locally relevant research which puts African and South African indigenous knowledge systems at the centre of scientific enquiry is slowly emerging. I include such emerging scholarly work on an annual basis into my curricula for different modules I teach. Further, I encourage critical thinking activities and co-construction of content in terms of what is learned during discussions in class.' (Respondent 87)

Some lecturer respondents followed student-centred approaches and included student voices in decolonising their curricula:

'Add in more context specific studies and examples. More interactions with students allowing them to take the lead. Ensuring more student-centred approaches are adopted.' (Respondent 32)

'Working through design strategies and assessment strategies to include alternative views. Adapting the lecturing method to allow for student voices.' (Respondent 47)

Criminology as a discipline needs to consider whether its teachings relate and reflect an African worldview, whether the curricula prepares students to engage with people from an African perspective and whether it is locally relevant (Van de Westhuizen, Greuel \& Beaukes 2017:4). Local relevance of curricula requires that Criminology develops knowledge, understanding and skills based on an exploration of 'life experiences, history and traditions of African people as the centre of analyses' (Thabede 2008:234). Academic staff members observed various challenges in their attempts to decolonise their curricula:

'Fighting against the "White is right" subculture. This is not blatant but often subtle.' (Respondent 61)

'The problem is that there are often different African explanations or interpretations for the same behaviour or phenomenon. In some cases, these insights are based on hearsay and word of mouth reports. It will be unethical to talk about ONE African explanation which makes the development of an African Criminology even more challenging.' (Respondent 71)

'There is limited written theories focusing on Afrocentrism. Most of African materials still seek approval from the global North for acceptance. All literature written by African is not well accepted by global South because they are the custodian of knowledge production (so they think).' (Respondent 77) 
Respondent 87: 'In the past, Afrikaans only lectures were not conducive to exposing students to diverse views and voices. In future, the slow pace at which locally relevant research is published, may delay the pace at which I am able to decolonise my curricula. As stated though, decolonisation of our curricula is an ongoing project and not a moment in time.'

The project of decolonisation and transformation cannot be performed without the involvement of students. As recipients of knowledge, students play a central role in decolonising the curriculum (Hendricks \& Leibowitz 2016). Student respondents provided various explanations as to why Criminology curricula needed to be decolonised:

'As a South African Criminology MA graduate, one would think I would be more informed with regards to what my country has to offer - with the wisdom that comes from African tradition, but I am not. It seems the answer is "just use Ubuntu", which is great, and I do, but I would like more African theory, more African-based intervention, more African voices not only in my findings but also in my literature review and theory chapters. I am working towards being part of that African voice, and I hope to be part of creating an inclusive and representative criminology for future students.' (Respondent 10)

Similar to the \#RhodesMustFall movement, student respondents raised questions about the relevance and appropriateness of the Criminology curriculum to the African context:

'Criminology is more based on the Western context, it is vital to learn about Criminology in an African context in order to easily relate and understand the content being studied.' (Respondent 22)

'Most of the curricula is biased, it gives too much focus only on Western perspectives which at times do not even relate to us Africans and our circumstances or how we experience crime. Therefore, it would be great and informative to have perspectives that focus on the experience of Africans.' (Respondent 36)

'The theory and methods currently being studied are out of tune with our lived experiences and realities. There is a desperate need for an understanding of our own ways, that may, in effect, contribute towards the better understanding and management of high rates of crime within the African continent.' (Respondent 85)

Transforming the Criminology curriculum will involve incorporating multiple independent pedagogies. Criminology theories must be generated and informed by life as it is lived, experienced and understood by local inhabitants and underpinned by the African local experience (Mgqwashu 2016). Students appear to be aware of their responsibility in decolonising and transforming Criminology:

'Challenging the West as credible knowledge producers by highlighting and learning about the African perspective on Criminology.' (Respondent 35)

'Perhaps challenging/critiquing certain views/theories presented by the Western world.' (Respondent 37)

'To incorporate African theories into my research and to consider things from the perspectives of other cultural groups.' (Respondent 44)

\section{Discussion}

South African universities have been built on the foundations of Western models, which have always dehumanised the experiences and knowledge of the colonised (Le Grange 2019:34). To decolonise the curriculum, Western knowledge ought to be decentralised and African knowledge moved from the margin to the centre, as was advocated by Ngugi wa Thiong'o (1986) decades ago. The purpose of this study was to explore the extent to which Criminology curricula incorporates African perspectives as perceived by students and lecturers across South African IHL. The results indicate that all the academic staff and nearly all the postgraduate students had heard of decolonisation before. More than half of the academic staff were familiar with the notions of decolonisation even prior to the \#RhodesMustFall student protest action, yet the decolonial project only gained momentum in the context of rapid political change triggered by the student movements (Mahmood 2019:16). It was only in the wake of the 2015 and 2016 student protest action that institutions developed policy frameworks and plans geared towards decolonisation and transformation. These policy frameworks and plans were an attempt to formalise transformation and provide guidance for lecturers to transform and decolonise their curricula. Clearly there was a level of awareness about decolonisation amongst academics, but very limited - if any - action prevailed on the part of universities and academics to ensure that decolonisation took place. This paralysis of action is concerning since the protest action occurred more than two decades after the dismantling of apartheid. Although not a new phenomenon (cf. Fanon 1963; Mbembe 2001; Nkrumah 1965; Thiong'o 1986), very limited empirical work and scientific output featured regarding decolonisation before \#RhodesMustFall.

Decolonisation and transformation of higher education slumbered given the academic profile of staff at South African universities. Lange (2019) explored how the student protest actions played out at the University of Free State (UFS) and the UCT, which are both historically white universities. The student protest action had little to no impact at UFS, with students receiving minimal support from academic staff. Yet UCT, where the student movement and the call to decolonise the university curriculum ignited, had a mass of black academics to support and encourage students, which was not the case at UFS given that the bulk of academic staff members were white people (Lange 2019:79-80). Limited action from the academic staff might explain why so few students learnt about decolonisation through their course material. It is important to note that student respondents from this study were at postgraduate level, who might read outside their curriculum and have come across decolonisation as part of their own research. The results suggest that the media and advocacy were the main drivers to challenge the slow pace of decolonising IHL and their curricula.

Respondents acknowledged that African understandings need to be on an equal footing as Western perspectives, but they presented more nuanced understandings of the 
intersections between power, hierarchy, knowledge production and dissemination. Conflict and critical Criminology - which focuses on power relations - are standard components of undergraduate teaching and learning, yet it appears that Criminology lecturers are reluctant to cast these interrogative lenses on their own discipline. What is clear from the results is that a reconsideration is needed in terms of the curriculum regarding inclusivity. Inclusiveness in terms of different perspectives and worldviews is an important element of decolonisation (Ndlovu-Gatsheni \& Zondi 2016:4). Furthermore, there is a need for dialogue on decolonisation and the questioning of existing epistemologies, as well as the grounding of educational paradigms in indigenous systems of knowledge. The student protests made students aware of the need for transformation and decolonisation and the results suggest that there is acknowledgement in the curriculum for students to understand the origins of Criminology in its historical context. The academic staff members acknowledged the need to decolonise the discipline, but the practical basis of exactly how a decolonised Criminology curriculum will play out in learning appears wanting, for example, regarding the casual nature of crime and criminality from indigenous stances. Some inroads have been made, especially in the form of child justice interventions and victim offender mediation where local philosophies and practices have infused remedial measures (cf. Steyn \& Sadiki 2018). Still, much more needs to be done to develop a truly transformed, African Criminology.

A worrying result relates to the low curricula intensity of engaging students with diverse local and global perspectives, as well as limited opportunities for Criminology students to critically grapple with issues of discrimination, racism, inequality and exclusion. The results are not surprising given the disciplines reluctance to engage and explore the relationship between race and crime (Choak 2020:46). These themes appear to be absent in the Criminology curriculum and the gap opens the door for curriculum developers to include frameworks such as intersectionality and Zemiology in their teaching and learning. In addition, more should be done to include hate crime and racism in the Criminology curriculum. Students appear aware of the shortfalls of the Criminology curriculum with regards to an appreciation of diverse entry points and opportunities to widen circles of contact or experiences in their learning. In the past, double or parallel tuition, according to language, created structural divides between different race groups of students and lecturers. Although this was mostly abolished (and only recently so) at former Afrikaans Whites-only institutions of higher education, the removal of such barriers could strengthen wider circles of learning among students. What is further evident is the mismatch between lecturers and students' views about the curriculum. The results suggest that Criminology lecturers are not engaging students on curriculum content, and they have little insight as to what students think about the curricula they study. Even though many universities have student feedback evaluations, these relate more to lecturers' performance than matters of curriculum and that could be a valuable opportunity to gauge students' views and needs in terms of (a transformed) curriculum. As the end-users of the curriculum, academics may benefit from engaging and collaborating with students to decolonise and transform their curriculum.

Awareness about shortfalls in the curriculum is present yet changes to the curriculum content lag. The student voices are clear about the lack of indigenous perspectives in Criminology and the appropriateness of the learning content, including the relevance of Western theory to African conditions and cultures. Much has been written on African traditional forms of conflict resolution such as the Gacaca courts in Rwanda, the mato oput in Uganda and inkundla/ lekgotla amongst the Sotho and Xhosa people in South Africa (Murithi 2009:228; Sadiki 2020:647-651; Wasonga 2009:31-32) although such knowledge is conspicuously absent in local Criminology curricula. Similarly, some voices about the methods of knowledge production emerged in Criminology (cf. Dastile 2017; Keikelame \& Swartz 2019), but they appear unable to gain track in local research practice. More work is needed that embraces a research methodology that fosters an understanding of local experiences of crime and its origins and management.

The results suggest some level of apathy amongst White Criminology lecturers towards the transformation and decolonisation of their curriculum. White scholars may be more comfortable with Western understandings of crime and criminality given their unfamiliarity with Black culture and traditions. One of the barriers to the decolonial project is the desire to maintain the status quo, which upholds and supports White supremacy, patriarchy, gender inequality and racism (Mehdi \& Jameela 2021:151). A major drawback of the decolonial project in Criminology would be for White academics to sit on the side-line and not critically engage in the decolonisation scholarship. All academic scholars, regardless of race, can make meaningful contributions to decolonising the university curriculum. Given that the Criminology curriculum is more than just a selection of study material, the belief systems and attitudes of academics are central to transforming and decolonising the curriculum. To decolonise and transform the curriculum, all academics will need to collaborate and engage in rigorous debates concerning the curriculum of the discipline.

\section{Conclusion}

Decolonisation of universities has sometimes incorporated cosmetic changes, such as the renaming of buildings and updating policies, vision and mission statements, without real structural changes and thoroughly decolonising the curriculum and institutional frameworks. In the context of the present article, the debate is not whether Criminology curriculum needs to decolonise because the answer is yes, it does, and urgently so. Even with the call to include indigenous perspectives and to decolonise the discipline, South African Criminology has continued with a 'business as usual' mindset. Despite this, paradigms and frameworks are 
malleable. For example, feminist perspectives in Criminology have helped to develop theoretical frameworks to explain female criminality (cf. Artz, Hoffman-Wanderer \& Moult 2021). In a similar vein, a decolonised Criminology curriculum can flourish by diversifying the discipline and its theoretical approaches. Criminology must interrogate and engage in decolonial debates not as a matter of black people and white people, but as one of equipping Criminology students to respond to the crime phenomenon in a manner that places Africa at the centre of the criminological analysis.

The focus should now shift to actions that will ensure a truly decolonised Criminology. In its present form, Criminology in Africa will add little to no value in understanding crime and criminality without a strong nucleus of African perspectives, experiences and practices. Western knowledge is not universal, therefore, the Criminology curriculum should be embedded in the socio-cultural context of South Africa and the broader continent. We found evidence that the current Criminology curriculum is far removed from the lived experiences, cultures and identities of students who must take up the baton for future crime prevention and reduction. Without immediate structural changes to the Criminology curricula, Western dominance will continue to prevail in the teaching and learning - and eventual practice - of Criminology in South Africa.

To our knowledge, this article is the first attempt at determining views about decolonisation in South African Criminology, as available research has predominantly been literature and qualitative studies. Future research should critically analyse the Criminology curricula in South Africa, whilst at the same time being sensitive to the varying content and Criminology curricula across different universities. In addition, the apathy of some scholars to the decolonisation project should be explored, as well as the views of Criminology practitioners and undergraduate Criminology students.

\section{Acknowledgements Competing interests}

The authors declare that they have no financial or personal relationships that may have inappropriately influenced them in writing this article.

\section{Authors' contributions}

L.S., a PhD candidate conducted the research-administered the survey and did the write up of the entire article. F.S., who is the supervisor, did the data analysis via Statistical Package for the Social Sciences (SPSS), provided supervision throughout the project and edited the article and final analysis.

\section{Funding information}

This work was supported by the National Research Foundation South Africa under Grant 129432.

\section{Data availability}

The data is not available in the public domain at present, because future publications are foreseen.

\section{Disclaimer}

The views and opinions expressed in this article are those of the authors and do not necessarily reflect the official policy or position of any affiliated agency of the authors, and the publisher.

\section{References}

Agozino, B., 2004, 'Imperialism, crime and criminology: Towards the decolonisation of criminology', Crime, Law and Social Change 41, 343-358. https://doi.org/10.1023/ B:CRIS.0000025766.99876.4c

Agozino, B., 2010, 'Editorial: What is criminology? A control-freak discipline!', African Journal of Criminology and Justice Studies 4(1), i-xx.

Anyanwu, K.C., 1983, The African experience in the American market place a scaring indictment of western scholars and their distortion of African culture, Exposition Press, New York, NY.

Artz, L., Hoffman-Wandere, Y. \& Moult, K., 2021, Hard time(s): Women's pathways to crime and incarceration, The Gender, Health and Justice Research Unit, University of Cape Town.

Babbie, E., 2016, The practice of social research, 14th edn., Wadsworth, Cengage Learning, Belmont, TN.

Chimakonam, J.O., 2019, Ezumezu: A system of logic for African philosophy and studies, Springer, Cham.

Choak, C., 2020, 'British criminological amnesia: Making the case for a black and postcolonial feminist criminology', Decolonization of Criminology and Justice 2(1), 37-58. https://doi.org/10.24135/dcj.v2i1.17

Creswell, J.W. \& Creswell, J.D., 2018, Research design: Qualitative, quantitative, and mixed methods approaches, 5th edn., Sage, London.

Cunneen, C. \& Rowe, S., 2014, 'Changing narratives: Colonised peoples, Criminology and Social Work', International Journal for Crime, Justice and Social Democracy 3(1), 49-67. https://doi.org/10.5204/ijcjsd.v3i1.138

Dastile, N., 2017, "Breaking bread with female "criminals": Towards generation of testimonial knowledge on female criminality in South Africa', Gender and Behaviour 15(3), 9722-9738.

De Vos, A., Strydom, H., Fouche, C. \& Delport, C., 2011, Research at grass roots: For social sciences and human services professions, Van Schaik Publishers, Pretoria.

Deckert, A., 2014, 'Neo-colonial Criminology: Quantifying the silence', African Journal of Criminology and Justice Studies 8(1), 39-60.

Denzin, N.K, Lincoln, Y.S. \& Smith, L.T., 2008, Handbook of critical and indigenous methodologies, Sage, Los Angeles, CA.

Fanon, F., 1963, The wretched of the Earth, Ballantine, New York, NY.

Foucault, M., 1977, Discipline and punish: The birth of the prison, Pantheon Books, New York, NY.

Garuba, H., 2015, 'What is an African Curriculum?', Mail \& Guardian, viewed 29 July 2021, from https://mg.co.za/article/2015-04-17-what-is-an-africancurriculum/.

Heleta, S., 2016, 'Decolonisation of higher education: Dismantling epistemic violence and Eurocentrism in South Africa', Transformation in Higher Education 1(1), 1-8. https://doi.org/10.4102/the.v1i1.9

Hendricks, C., \& Leibowitz, B., 2016, 'Decolonising Universities isn't an Easy Process But it has to Happen', The Conversation, viewed May 2021, from https:// theconversation.com/decolonising-universities-isnt-an-easy-process-but-it-hasto-happen-59604.

Higgs, P., 2012, 'African philosophy and the decolonisation of education in Africa: Some critical reflections', Educational Philosophy and Theory 44(2), 37-55.

IBM, 2020, IBM SPSS Statistics for Windows, Version 27.0, IBM Corp, Armonk, NY.

Jansen, J.D., 2019, 'On the politics of decolonisation: Knowledge, authority and the settled curriculum', in J.D. Jansen (ed.), Decolonisation in universities: The politics of knowledge, pp. 29-47, Johannesburg, Wits University Press.

Kalunta-Crumpton, A., 2004, 'Criminology and orientalism', in A. Kalunta-Crumpton \& B. Agozino (eds.), Pan-African issues in crime and justice. Interdisciplinary research eries in ethnic, gender and class relations, Ashgate Publishing Limited.

Keet, A., 2014, 'Epistemic "othering" and the decolonisation of knowledge', Africa Insight 44(1), 23-37.

Keikelame, M.J. \& Swartz, L., 2019, 'Decolonising research methodologies: Lessons from a qualitative research project, Cape Town, South Africa', Global Health Action 12(1), 1-7. https://doi.org/10.1080/16549716.2018.1561175

King, S., 2017, 'Colonial Criminology: A survey of what it means and why it is important', Sociological Compass 11(3), 1-11. https://doi.org/10.1111/soc4.12447

Kumar, R., 2014, Research methodology: A step-by-step guide for beginners, 4th edn., Sage, London. 
Lange, L., 2019, 'The institutional curriculum, pedagogy and the decolonisation of the South African university', in J.D Jansen (ed.), Decolonisation in universities: The politics of knowledge, pp 79-99, Wits University Press, Johannesburg.

Le Grange, L., 2019, 'The curriculum case for decolonisation', in J. Jansen (ed.) Decolonisation in universities: The politics of knowledge, pp. 29-47, Wits University Press, Johannesburg.

Luckett, K., 2010, 'Knowledge claims and codes of legitimation: Implications for curriculum re-contextualisation in South African higher education', Africanus 40(1), 4-18

Mackinlay, E. \& Barney, K., 2014, 'Unknown and unknowing possibilities: Transformative learning, social justice and decolonizing pedagogy in indigenous Australian studies', Journal of Transformative Education 12(1), 54-73.

Mahmood, M., 2019, 'Decolonising universities', in J.D. Jansen (ed.), Decolonisation in universities: The politics of knowledge, pp. 15-28, Wits University Press, Johannesburg.

Maree, K. \& Pietersen, J., 2017, 'Surveys and the use of questionnaires', in K. Maree, J.W. Creswell, L. Ebersohn, I. Eloff, R. Ferreira, N.V. Ivankova et al. (eds.), First steps in research, 2nd edn., Van Schaik Publishers, Pretoria.

Mbembe, A., 2001, On the postcolony, University of California Press, Los Angeles.

Mehdi, N. \& Jameela M., 2021, 'On the fallacy of decolonisation in our higher education institutions (HEIs)', in D.S.P Thomas \& J. Arday (eds.), Doing equity and diversity for success in higher education, pp. 151-16, Palgrave Macmillan, London.

Mgqwashu, E., 2016, 'Universities can't decolonise the curriculum without defining it first', The Conversation, viewed 26 July 2018, from https://theconversation.com/ universities-cant-decolonise-the-curriculum-without-defining-it-first-63948.

Moosavi, L., 2018, 'Decolonising Criminology: Syed Hussein Alatas on Crimes of the Powerful', Critical Criminology 27(2), 229-242. https://doi.org/10.1007/s10612018-9396-9

Mswazie, J. \& Mudyahoto, T., 2013, 'Africanizing the curriculum: An adaptive framework for reforming African education systems', Journal of Merging Trends in Educational Research Policy Studies 4(1), 170-177.

Murithi, T., 2009, 'An African perspective on peace education: Ubuntu lessons in reconciliation', International Review of Education 55, 221-233. https://doi. org/10.1007/s11159-009-9129-0

Kalunta-Crumpton, A., 2004, 'Criminology and orientalism', in A. Kalunta-Crumpton \& B. Agozino (eds.), Pan-African issues in crime and justice. Interdisciplinary research series in ethnic, gender and class relations, pp $5-22$, Ashgate Publishing Limited Aldershot.

Ndlovu-Gatsheni, S.J. \& Zondi, S., 2016, Decolonizing the university, knowledge systems and disciplines in Africa, Carolina Academic Press, Durham.
Neuman, W.L., 2014, Social research methods: Qualitative and quantitative approaches, Pearson Education Limited, London.

Ngugi, W.T.F., 1986, Decolonising the mind: The politics of language in African literature, East African Educational Publishers Ltd., Nairobi.

Nkrumah K., 1965, Neo-colonialism, the last stage of imperialism, Thomas Nelson \& Sons, London.

Qualtrics, 2020, Qualtrics: Experience management company, Seattle, Washington.

Sadiki, L., 2020, 'Towards an African criminology', in C. Bezuidenhout (ed.), A Southern African perspective on fundamental criminology, pp. 640-668, Pearson, Cape Town.

Schucan Bird, K. \& Pitman, L., 2020, 'How diverse is your reading list? Exploring issues of representation and decolonisation in the UK', Higher Education 79(5), 903-920.

Shay, S., 2016, 'Urgent strategy needed to decolonise university curricula', Mail \& Guardian, viewed 29 July 2021, from https://mg.co.za/article/2016-06-20-00urgentstrategy-needed-to-decolonise-university-curricula-no-longer-a-luxuryurgentstrategy-n
but-a-necessity/.

Steyn, F. \& Sadiki, L., 2018, 'Diversion', in C. Bezuidenhout (ed.), Child and youth misbehaviour in South Africa: A holistic approach, 4th edn., Van Schaik, Pretoria.

Thabede, D., 2008, 'The African worldview as the basis of praxis in the helping professions', Social Work/Maatskaplike Werk 44(3), 233-245. https://doi. org/10.15270/44-3-237

Thiong'o, N., 1986, Decolonising the mind: The politics of language in African literature, East African Educational Publishers Ltd., Nairobi.

Udefi, A., 2014, 'The rationale for an African epistemology: A critical examination of the Igbo views on knowledge, belief, and justification', Canadian Social Science 10(3), 108-117.

Van de Westhuizen, M., Greuel, T. \& Beaukes, J.W., 2017, 'Are we hearing the voices? Africanisation as part of community development', Theological studies 73(3), 1-9. https://doi.org/10.4102/hts.v73i3.4512

Wasonga, J., 2009, 'Rediscovering mato oput: The Acholi justice system and the conflict in northern Uganda', Africa Peace and Conflict Journal 2(1), 27-38.

Williams, P. \& Chrisman, L., 1995, Colonial discourse and post-colonial theory, Columbia University Press, New York, NY.

Zembylas, M., 2018, 'The entanglement of decolonial and posthuman perspectives: Tensions and implications for curriculum and pedagogy in higher education', Parallax 24(3), 254-267. 